\title{
Insecticidal Activity of Diverse Extracts of the Citrullus colocynthis (L.) Against the Blue Green Aphid Acyrthosiphon Kondoi Shinji
}

\author{
Naimah Asid Alanazi \\ Department of Biology, Faculty of Science, University of Hail, Jeddah, Saudi Arabia

\begin{abstract}
The efficiency of three different extracts from stem and leaf of Citrullus colocynthis against the blue green aphid Acyrthosiphon kondoi Shinji was studied. Results showed that the ethanolic extracts from the two parts of C.colocynthis caused higher mortalities of aphids after 48 hours (96\% and $93 \%$ for the stem and leaf, respectively). Toxicological parameters demonstrated that ethanolic extract from the stem of C.colocynthis was more toxic to aphids than leaf extract. This study suggests that detailed chemistry on the stem of $C$. colocynthis is required before applying it in the integrated pest management of aphids.
\end{abstract} \\ Keywords: Aphid Control, Bitter apple, Bioassay, Botanical insecticides, Extracts.
}

\section{Introduction}

Aphid is a major insect pest that damages crops by congregating on foliage parts of plant and sucking plant nutrients and transmit a wide range of plant viruses which cause huge yield losses (Shah et al., 2007; Davoodi Dehkordi et al., 2013; Asiry, 2015). The limited damage to tissues occurs during primary feeding and the prolonged interactions of aphid mouthparts with the plant cells cause plant responses to the distinctive feeding media of the chewing insects (Walling, 2000). In addition, many aphid species acquire resistance to pesticides, and some aphids develop their virulence profile to overcome plant-resistance genes. Environmental concerns associated with the use of insecticides have led to the development and cultivation of many aphid-resistant crops in the past century (Smith, 2005). Pesticides have played an important role in enhancing crop yields.): However, their extensive and wasteful uses have been caused a serious hazard to human and the environment. Sometime, aphid control with synthetic insecticides is not acceptable and has adverse effects such as pesticide residues, biodiversity loss, environmental pollution, destabilization of ecosystem and enhanced resistance to insecticides (Asiry, 2015). Therefore, there is a need to use eco-friendly and cost effective control methods such as plant botanicals. Plant botanicals are the secondary plant metabolites synthesized by the plant itself (Koul and Walia, 2009). For example, extract from hot pepper found to be more effective against pea aphid, Acyrthosiphon pisum Harris (Iqbal et al., 2011). Aphid incidence could managed by using 3\% Neem Kernel extract (in cow urine) alone as well as with combination of decreased amount of Dimethoate 0.03\% (Gupta, 2005). Aphid mortality was up to $90 \%$ due to tobacco leaf extract followed by Neem and garlic (Bahar et al., 2007). The highest concentration of botanical insecticides (from Azadirachta indica, Pongamia glabra and Chrysanthemum cinerariifolium) caused $100 \%$ mortality of the green peach aphid Myzus persicae, the red 
spider mite Tetranychus urticae and the Egyptian cotton leafworm Spodoptera littoralis (Pavela, 2007). Wabale and Kharde (2010) found that Ipomea fistulosa (99.41\%) and Pongamia pinnata L. (99.41\%) were the best plant extracts in managing the population of aphid. Asiry (2015) concluded that aqueous extracts from stems of bitter apple Citrullus colocynthis caused a higher mortality of the bird cherry-oat aphid, Rhopalosiphum padi (L.).

The objectives of this study is to investigate the effect of different solvent (aqueous, ethanolic and chloroform) for extract from stem and leaf of the bitter apple C. colocynthis by using several concentrations on controlling the blue green aphid (A. kondoi Shinji and Kondo) which is described as the most critical pests of alfalfa crops.

\section{Materials and Methods}

\subsection{Preparation of Citrullus colocynthis Extracts}

The preparation of plant extracts was carried out according to (Asiry, 2015) Bitter apple $C$. colocynthis plants were collected from Hail desert which is located in the north central part of Saudi Arabia. Combined impurities such as weeds, soil particles and other inessential matter were carefully removed from the gathered $C$. colocynthis plants. The collected samples of $C$. colocynthis were washed and shade-dried at room temperature. Dried plant materials were powdered using an electrical blender; $10 \mathrm{~g}$ of the powder was macerated separately in 100 $\mathrm{ml}$ of distilled water, ethanol and chloroform for $72 \mathrm{~h}$. The shaker was used to mix the crude preparation for 24 hours at room temperature and then centrifuged at $4000 \mathrm{rpm}$ for 20 minutes. This mixture was then relocated to a $250 \mathrm{ml}$ beaker and the solvent was evaporated at $60^{\circ} \mathrm{C}$ to concentrate the plant extract. Four concentrations were used 100, 200, 400 and 800 ppm by diluted it in different solvent.

\subsection{Collection of Aphids}

The blue green aphids $A$. kondoi were collected from pesticides-free alfalfa crop (Medicago sativa L.), Hail region, Saudi Arabia. The blue green aphid A. kondoi on their host plant were keptin plastic bags and were transferred and kept in the fridge in the laboratory for twenty-four hours before running the experiment.

\subsection{Toxicity Bioassay}

To evaluate the toxicity effect of different extracts (aqueous, ethanolic and chloroform) from the stem and leaf of the bitter apple $C$. colocynthis against the blue green aphid (A. kondoi Shinji and Kondo), leaves of alfalfa measuring $3 \mathrm{~cm}$ in length were separately dipped into the different extracts (aqueous, ethanolic and chloroform) of C. colocynthis with four different concentrations for 30 seconds and then air dried. Each leaf piece was placed in a Petri dish $(90 \mathrm{~mm}$ diameter $\times 15 \mathrm{~mm}$ deep) and 20 adults of $A$. kondoi were individually transmitted to the middle each leaf piece by using a soft hair brush. In this experiment, a completely randomized block design was used where collected aphids divided into 24 groups with regards to the plant (2 treatments (stem and leaf), solvents (3 solvents: aqueous, ethanolic and chloroform) and their concentrations (4 dilutions)). Each group replicated five times and each replicate had 20 adults of $A$. kondoi. Also, this experiment had controls in which aphids were placed in Petri dishes that contained non treated leaves of alfalfa. The Petri dishes were kept in an incubator at $25^{\circ} \pm 1$ and $40-50 \%$ humidity. After 24 and 48 hours, dead aphids were counted in the Petri dishes (Asiry, 2015; Nia et al., 2015; Alghamdi, 2018). 
The percentage of mean mortality of $A$. kondoi was performed using the following formula:

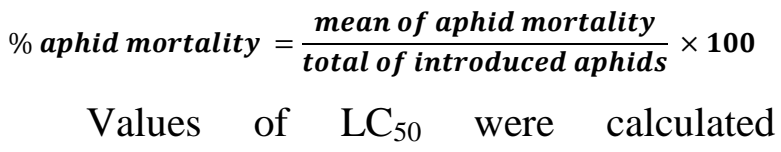
according to Finney 1971. Data were corrected for control mortality using Abbott's formula 1925.

\subsection{Data Analysis}

Results were adjusted using Abbot's formula and statistically computed according to Finney (1971). All statistical analyses were applied in the statistical package SPSS $^{\circledR} 14.0$ for Windows.

\section{Results and Discussion}

The treatment of the stem extract from the bitter apple $C$. colocynthis against the blue green aphid $A$. kondoi caused a higher mortality as shown in (Table 1). In the conducted experiment, toxicity effect of the stem part of the bitter apple $C$. colocynthis by different solvent: aqueous, ethanol and chloroform showed a significant effect on controlling the blue green aphid A. kondoi after 24 and 48 hours. All tested solvents from the stem of the bitter apple $C$. colocynthis were toxic to the blue green aphid $A$. kondoi in a dose dependent manner, although the toxicity effect was relatively low for aqueous extract. The stem extract of the bitter apple $C$. colocynthis was the most effective, where its $800 \mathrm{ppm}$ ethanolic and chloroform extracts caused 96 and $91 \%$ mortalities after 48 hours of exposure respectively, while the aqueous extract produced $88 \%$ mortality after the same period of exposure (Table 1). The ethanolic extracts of the stem of the bitter apple $C$. colocynthis was generally more toxic than the aqueous or chloroform extracts. Data showed that the highest percentage of aphids was killed consistently across the time after application by ethanolic leaf extracts compared with other solvents (Table 2). The mortality of $A$. kondoi was shown by the ethanolic leaf extract and followed by the chloroform and aqueous extracts which they showed 93, 89 and $85 \%$ mortality after 48 hours, respectively. The stem extract of the bitter apple $C$. colocynthis with all solvents demonstrated a higher mortality than leaf extract with the same solvents. The toxicity mechanism of aphids with the tested plant extracts can be attributed to the feeding deterrent (Schumutterer, 1990; Saxena et al., 1988). Nia et al., (2015) declared that Etheric extract of leaves of Artemisia herbaalba Asso, Eucalyptus camaldulensis Dehnh and Rosmarinus officinalis L. was effective and caused mortalities (100\%, $53 \%$ and $60 \%$ respectively) at the highest concentration. Also, phytochemical screening showed the richness of Terpenes in Etheric extract. The results of this study are in agreement with Rojht et al., (2012) which found out that the ethanol extract of Rosmarinus officinalis, Lavandula angustifolia and Ruta graveolens showed a higher repellent activity on the adult of Acanthoscelides obtectus and Leptinotarsa decemlineata. In addition, Asiry (2015) concluded that the aqueous extract from stem part of C. colocynthis is more effective in reducing aphid numbers compared with other parts.

In this study, $\mathrm{CL}_{50}$ calculated as the lethal concentrations causing $50 \%$ of mortality in the aphids treated with the stem and leaf extracts of the bitter apple $C$. colocynthis (The $\mathrm{LC}_{50}$ values and $95 \%$ confidence limits (CL) are given in Tables 3 and 4).

The range of acute $(24 \mathrm{hr})$ and chronic $(48 \mathrm{hr}) \mathrm{LC}_{50}$ values were $122.6-921.4,59.4-$ 511.4and 89.5-755.1 ppm for the aqueous, ethanolic and chloroform of leaf extracts, respectively (Table 3 ). Both the ethanolic and chloroform extracts of the bitter apple $C$. colocynthis were significantly lower $\mathrm{LC}_{50}$ s (48 
hr) than the aqueous extracts (24 and $48 \mathrm{hrs).}$ The ethanolic extract of the bitter apple $C$. colocynthis was generally more toxic than the aqueous or chloroform extracts. Table 4 demonstrated the $\mathrm{LC}_{50}$ for the effect of the stem extract with the three solvents against the blue green aphid A. kondoi. From this table, the ethanolic extract from the stem part of the bitter apple $C$. colocynthis was more toxic to aphid than the aqueous and chloroform extracts with 44.1, 101.5 and $70.2 \mathrm{ppm}$, respectively. These data confirmed that the ethanolic extract of the stem of the bitter apple C. colocynthis is more toxic to aphids than the other two solvents. Also, the stem extract of the bitter apple $C$. colocynthis with the three solvents is more toxic to aphids than the leaf extract. Soliman (2007) showed that Artemisia herbaalba oil gave a higher toxicity with $\mathrm{LC}_{50}$ $0.023 \%$ and caused $90.44 \%$ reduction in the population on Aphis gossypii (Glover). Mullai and Jebanesan (2007) examined the effect of bitter melon extract against the mosquito of Culex quinquefasciatus (Dip: Culicidae). Their results suggested that bitter melon extract has toxic and lethal effects on the studied insect and mortality enhanced with increasing concentration. The results of Rawi et al. (2011) indicated that the methylene chloride extract of the bitter melon has insecticidal effect on larvae of Spodoptera littoralis. According to the results of this study, it can be concluded that the blue green aphid A. kondoi has reasonable sensitivity to the bitter apple $C$. colocynthis extract specially with the stem extract. This study recommends that more detailed chemical analyses of the stem of the bitter apple $C$. colocynthis are required to understand the underlining mechanism of how the bitter apple $C$. colocynthis extracts control aphids. Thus, the stem extract of this plant could be introduced as an alternative to conventional synthetic pesticides aphid pests.

Table 1. Percentage of mortalities of the blue green aphid Acyrthosiphon kondoi after treatment with stem extract of the bitter apple Citrullus colocynthis.

\begin{tabular}{|c|c|c|c|c|c|c|c|}
\hline \multirow[t]{3}{*}{ Plant Materials } & \multirow{3}{*}{$\begin{array}{l}\text { Conc. } \\
\text { Ppm }\end{array}$} & \multicolumn{2}{|c|}{ Aqueous Extract } & \multicolumn{2}{|c|}{ Ethanolic Extract } & \multicolumn{2}{|c|}{ Chloroform Extract } \\
\hline & & \multicolumn{6}{|c|}{$\%$ Mortality after (hrs) } \\
\hline & & 24 & 48 & 24 & 48 & 24 & 48 \\
\hline Stem extract & $\begin{array}{l}800 \\
400 \\
200 \\
100 \\
\text { Cont. }\end{array}$ & $\begin{array}{r}45 \\
41 \\
35 \\
30 \\
0.0\end{array}$ & $\begin{array}{c}88 \\
80 \\
73 \\
70 \\
0.0\end{array}$ & $\begin{array}{l}60 \\
52 \\
45 \\
40 \\
2.0\end{array}$ & $\begin{array}{c}96 \\
88 \\
84 \\
80 \\
0.0 \\
\end{array}$ & $\begin{array}{c}54 \\
47 \\
42 \\
37 \\
0.0\end{array}$ & $\begin{array}{l}91 \\
85 \\
80 \\
76 \\
0.0\end{array}$ \\
\hline
\end{tabular}

Table 2. Percentage of mortalities of the blue green aphid Acyrthosiphon kondoi after treatment with leaf extract of the bitter apple Citrullus colocynthis.

\begin{tabular}{|c|c|c|c|c|c|c|c|}
\hline \multirow[t]{3}{*}{ Plant Materials } & \multirow{3}{*}{$\begin{array}{l}\text { Conc. } \\
\text { Ppm }\end{array}$} & \multicolumn{2}{|c|}{ Aqueous Extract } & \multicolumn{2}{|c|}{ Ethanol Extract } & \multicolumn{2}{|c|}{ Chloroform Extract } \\
\hline & & \multicolumn{6}{|c|}{$\%$ Mortality after (hrs) } \\
\hline & & 24 & 48 & 24 & 48 & 24 & 48 \\
\hline \multirow[t]{5}{*}{ Leaf extract } & 800 & 45 & 85 & 55 & 93 & 50 & 89 \\
\hline & 400 & 36 & 77 & 47 & 85 & 45 & 82 \\
\hline & 200 & 32 & 70 & 40 & 80 & 40 & 75 \\
\hline & 100 & 28 & 55 & 35 & 68 & 35 & 60 \\
\hline & Cont. & 0.0 & 0.0 & 0.0 & 0.0 & 2.0 & 0.0 \\
\hline
\end{tabular}


Table 3. Insecticidal activity of the bitter apple Citrullus colocynthis leaf extract against the blue green aphid Acyrthosiphon kondoi.

\begin{tabular}{|l|l|l|l|l|l|}
\hline Leaf extracts & $\begin{array}{l}\text { Bioassay } \\
\text { Time }\end{array}$ & $\begin{array}{l}\text { Regression of NED } \\
\text { response(Y) on } \\
\text { close }(\mathrm{X})\end{array}$ & $\mathrm{Lc}_{50}$ (Conf. limits) ppm & Slope & $\mathrm{P}$ \\
\hline Water & & & & & \\
& $24 \mathrm{~h}$ & $\mathrm{Y}=-1.60+0.50 \mathrm{X}$ & $921.4(393.12-1008.42)$ & 0.50 & 0.878 \\
Ethanol & $48 \mathrm{~h}$ & $\mathrm{Y}=-1.81+0.98 \mathrm{X}$ & $122.6(99.81-324.33)$ & 0.81 & 0.821 \\
& $24 \mathrm{~h}$ & $\mathrm{Y}=-1.54+0.57 \mathrm{X}$ & $511.4(274.12-769.14)$ & 0.57 & 0.96 \\
Chloroform & $48 \mathrm{~h}$ & $\mathrm{Y}=-1.63+1.05 \mathrm{X}$ & $59.4(48.22-88.20)$ & 1.06 & 0.81 \\
& $24 \mathrm{~h}$ & $\mathrm{Y}=-1.31+4.51 \mathrm{X}$ & $755.12(299.74-1066.32)$ & 0.4 & 0.99 \\
& $48 \mathrm{~h}$ & $\mathrm{Y}=-1.84+1.06 \mathrm{X}$ & $89.51(56.33-104.89$ & 1.035 & 0.84 \\
\hline
\end{tabular}

$\mathrm{LC}_{50}=$ lethal concentration killing $50 \%$ of the insects.

Table 4. Insecticidal activity of the bitter apple Citrullus colocynthis stem extract against the blue green aphid Acyrthosiphon kondoi.

\begin{tabular}{|l|l|l|l|l|l|}
\hline Stem extracts & $\begin{array}{l}\text { Bioassay } \\
\text { Time }\end{array}$ & $\begin{array}{l}\text { Regression of NED } \\
\text { response(Y) on } \\
\text { close }(\mathrm{X})\end{array}$ & $\mathrm{Lc}_{50}$ (Conf. limits) ppm & Slope & $\mathrm{P}$ \\
\hline Water & & & & & \\
Ethanol & $24 \mathrm{~h}$ & $\mathrm{Y}=-1.42+0.45 \mathrm{X}$ & $801.5(327.11-987.13)$ & 0.44 & 0.98 \\
& $48 \mathrm{~h}$ & $\mathrm{Y}=0-.93+0.70 \mathrm{X}$ & $101.5(88.71-321.11)$ & 0.70 & 0.68 \\
Chloroform & $24 \mathrm{~h}$ & $\mathrm{Y}=-1.40+0.56 \mathrm{X}$ & $281.4(106.91-409.31)$ & 0.87 & 0.45 \\
& $48 \mathrm{~h}$ & $\mathrm{Y}=-0.96+0.87 \mathrm{X}$ & $44.11(35.24-88.220)$ & 0.88 & 0.44 \\
& $24 \mathrm{~h}$ & $\mathrm{Y}=-1.29+0.47 \mathrm{X}$ & $401.31(244.37-799.22)$ & 0.47 & 0.89 \\
& $48 \mathrm{~h}$ & $\mathrm{Y}=-0.68+0.68 \mathrm{X}$ & $70.21(66.22-305.66)$ & 0.68 & 0.86 \\
\hline
\end{tabular}

$\mathrm{LC}_{50}=$ lethal concentration killing $50 \%$ of the insects.

\section{Acknowledgment}

The Author gratefully acknowledges the Department of Biology, Faculty of Science, University of Hail, Saudi Arabia for the facility and support.

\section{References}

Abbot, W. S. (1925). A method of computing the effectiveness of an insecticide. J. Econ. Entomol., 18: 265267.

Alghamdi, A.S. (2018). Insecticidal effect of four plant essential oils against two aphid species under laboratory conditions. Journal of Applied Biology \& Biotechnology, 6(2): 27-30.

Asiry, K. A. (2015). Aphidicidal activity of different aqueous extracts of bitter apple Citrullus colocynthis (L) against the bird cherry-oat aphid Rhopalosiphum padi(L) (Homoptera: Aphididae) under laboratory conditions. $J$. Anim. Plant Sci., 25(2): 456-462.

Bahar, M.H., Islam, M. A., Mannan, A. and Jashim Uddin, M. (2007). Effectiveness of some botanical extracts on bean aphids attacking Yearlong Beans. J. Entomol., 4(2): $136-142$

Davoodi Dehkordi, S., Sahragard, A. and Hajizadeh, J., (2013). The Effect of Prey Density on Life Table
Parameters of Hippodamia variegata (Coleoptera: Coccinellidae) Fed on Aphis gossypii (Hemiptera: Aphididae) under Laboratory Conditions. ISRN Entomology, 2013: 1-7.

Finney, D. J. (1971). Probability Analysis. 3rd edn. Cambridge University Press, Cambride, pp. 318-319.

Gupta, M.P. (2005). Efficacy of neem in combination with cow urine against mustard aphid and its effect on coccinelid predator. $J N K V V .4(2)$.

Iqbal, M. F., Kahloon, M. H., Nawaz, M. R. and Javaid, M.I. (2011). Effectiveness of some botanical extracts on wheat aphids. The Journal of Animal \& Plant Sciences, 21(1): 114-115.

Koul, O. and Walia, S. (2009). Comparing impacts of plant extracts and pure allelochemicals and implications for pest control, CAB Reviews, 4: 1-30.

Mullai, K. and Jebanesan, A. (2007). Larvicidal, ovicidal and repellent activities of the leaf extract of two cucurbitaceous plants against filaria vector Culex quinquefasciatus (Say) (Diptera: Culicidae). J. Tropic. Biomed., 24(1): 1-6.

Nia, B.; Frah, N. and Azoui I. (2015). Insecticidal activity of three plants extracts against Myzus persicae (Sulzer) and their phytochemical screening. Acta agric. Slovenica, 2: $261-267$.

Pavela, R. (2007). Possibilities of botanical insecticide exploitation in plant protection. Pest Technology, 1: 47-52. 
Rawi, S. M., Bakry, F. A. and Al-Hazmi, M. A. (2011). Biochemical and histopathological effect of crude extracts on Spodoptera littoralis larvae. J. Evolution. Bio. Res., 3 (5): 67-78.

Rojht, H., Košir, I.J. and Trdan, S. (2012). Chemical analysis of three herbal extracts and observation of their activity against adults of Acanthoscelides obtectus and Leptinotarsa decemlineata using a video tracking system. J. Plant Dis.Protect.119 (2): 59-67.

Saxena, R.C., Jilani, G. and Abdul-Kareem, A. (1988). Effects of neem on stored grain insects. In: Focus on Phytochemical Pesticides, Vol. 1The Neem Tree, ed. M. Jacobson, pp. 97-111. CRS, Boca Raton, Fl, USA.

Schumutterer, H. (1990). Properties and potential of natural pesticides from the neem tree, Azadirachta indica. Annu. Rev. Entomol. 35: 271-297.
Smith, C.M. (2005). Plant Resistance to Arthropods: Molecular and Conventional Approaches. Springer, Dordrecht, The Netherlands, $423 \mathrm{p}$.

Soliman, M.M.M. (2007). Phytochemical and toxicological studies of Artemisia L. (Compositae) essential oil against some insect pests. Arch. Phyt. Plant Prot. 40 (2): 128-138.

Walling, LL. (2000). The myriad plant responses to herbivores. J. Plant Growth Regul., 19: 195-216.

Wabale, A.S. and Kharde, M. (2010). Bioefficacy of Plant Extracts against Sugarcane Woolly Aphid (Ceratovacuna Lanigera Zehntner.). Asian J. Exp. Biol. Sci., 1(3):592595.

Shah, S. I. A., Khan, I. A., Hussain, Z., Ahmad and M., Ahmad, S. (2007). Comparing the effectiveness of a biopesticide with three synthetic pesticides for aphid control in wheat. Sarhad J. Agric., 23(3): 723-728. 


\section{النشاط الإبادي لمستخلصات منتوعة من نبات الحنظل (سيترولوس كولوسينشس) ضد آفة المن الأخضر المزرق \\ نعيمه عصيد العنزي}

قسم الأحباء، كلية العلوم، جامعة حائل، المدلكة العربية السعودية

المستخلص. تمت دراسة فعالية مستخلصات مختلفة من ساق وأوراق الحنظل ضد آفة المن

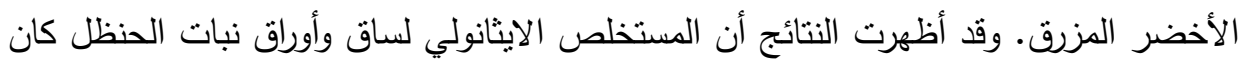

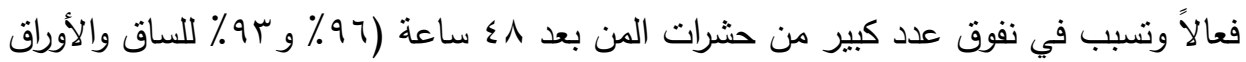

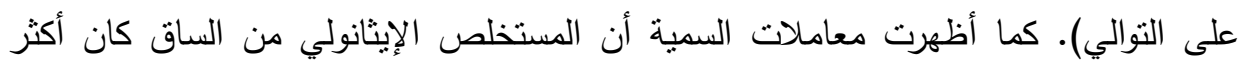

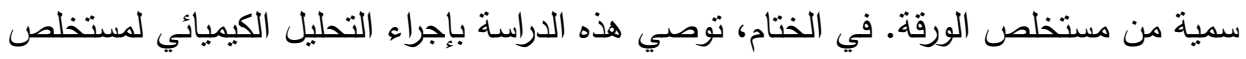
ساق الحنظل قبل استخدامه كمبيد في الإدارة المنكاملة لأقات المن. كلمات مفتاحية: نبات الحنظل، تقييم حيوي، مبيدات نباتية، مستخلصات، مكافحة المن. 
